DOI: 10.20472/IAC.2019.048.028

PATHOMPONG KOOKKAEW

Rajamangala University of Technology Suvarnabhumi, Thailand

\title{
COST AND RETURN ON INVESTMENT FROM RICE RD41 FARMING OF THE FARMERS IN SAMCHUK DISTRICT, SUPHANBURI PROVINCE, THAILAND
}

\begin{abstract}
:
The purposes of this research study were 1) to study cost and return on investment from rice RD41 farming of the farmers in Samchuk district, Suphanburi province 2) to analyze cost and return on investment from rice RD41 farming of the farmers in this area. The sample of 10 farmers who were member of Samchuk Agricultural Cooperative having rice farms which the area between 10 to 50 rai, drawn by the method of purposive sampling because the management methods of rice farm did not different. The study was conducted by collecting data and analyzing the data obtained by in-depth interviews, the tool was interview questions. Quantitative data were analyzed using the following cost, profit, Net profit to cost ratio, Net profit to sales ratio, Return on investment and break-even point.

Results of cost and return indicated that total average cost was $4,420.25$ baht per rai, while average net profit was $1,209.86$ per rai. Net profit to cost ratio was $26.37 \%$, while net profit to sales ratio was $20.01 \%$. Return on investment (ROI) was $22.54 \%$ and break-even point was 0.21 tons per rai. Cost of rice RD41 comprised 3 important costs which were $12.06 \%$ of raw material cost, $35.59 \%$ of labor cost and $52.35 \%$ of overhead cost.
\end{abstract}

\section{Keywords:}

Cost, Return, Ratio, Rice RD41, Rice cultivation

JEL Classification: D24, M19, Q19 


\section{Introduction}

Thailand is an agricultural country since ancient times. Most of the country's agriculture has grown rice as the main crop and can be grown in every region throughout the country with a total area of 70.42 million rai for the 2018/19 production year (Office of the Plan and Policy, 2018). In addition, rice is an important economic crop that can generate income from the country each year (Thongdeerawisuraket P., 2016). The statistics of rice export data in 2018 totaled 180,270.06 million baht and increased from 2.92\% in 2017 (Thailand Trading Report, 2018).

Table 1: Value of Thai rice exports.

\begin{tabular}{ccc}
\hline Year & Value (Million Baht) & Growth Rate (Percentage) \\
\hline 2014 & $174,852.41$ & - \\
2015 & $155,912.02$ & -10.83 \\
2016 & $154,690.45$ & -0.78 \\
2017 & $175,160.78$ & 13.23 \\
2018 & $180,270.06$ & 2.92 \\
\hline
\end{tabular}

Source: Thailand Trading Report, 2018

Suphanburi province has a total area of $1,194,842$ rai for rice cultivation, separated into rice growing areas in Sam Chuk District on both in-season rice and off-season rice, 116,923 rai (Suphanburi provincial agricultural extension office, 2018) and some areas can grow rice up to 3 times a year or 5 times per 2 years. The rice varieties used to grow are rice varieties RD 21, RD 41, Chai Nat 1, Suphanburi 90 and Thai Jasmine rice etc. (Social Economic Information Suphanburi Province, 2018). However, farmers are required to use chemical fertilizers and various chemicals in maintenance to increase productivity and get the greatest return in the present day which result in an increase in the cost of growing rice, such as weeds and pests Including expensive oil prices and higher wages.

From these problems, the researcher is interested in studying and analyzing the cost and return on investment in the cultivation of rice, RD 41, which is a popular cultivar of farmers in Sam Chuk District, Suphanburi in order to consider the results as information and guidelines for farmers or stakeholders to make investment decisions for growing rice varieties of RD 41.

\section{Research Objectives}

To study and analyze the cost and return of investment in the cultivation of RD 41 rice of the farmers in Sam Chuk, Suphanburi. 


\section{Literature Review}

\section{General information about rice, RD41}

\section{Figure 1: Rice plant, RD 41}

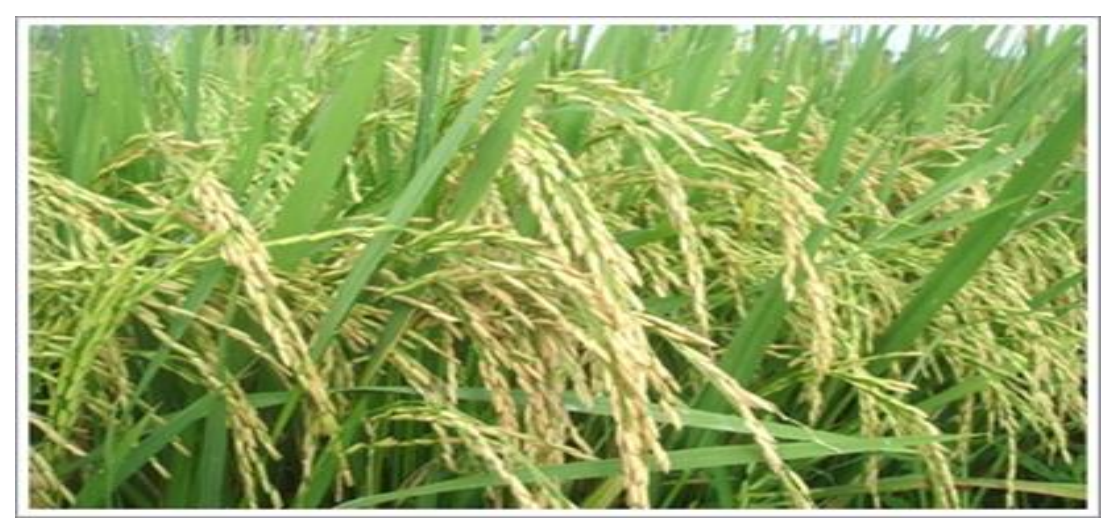

Source: Rice Department, 2018

Rice that has been certified by the Department of Rice Conservation Committee to approve the breed name KorKhor. 41 and recommended that farmers should grow on September 17, 2009 and have tested the acceptance of farmers. From the season 2004 to the season 2007, the farmer fields in Phitsanulok, Phichit, Sukhothai, Phrae, Ubon Ratchathani, Sakon Nakhon, Surin, Pathum Thani and Suphanburi. This rice variety is not sensitive to light and can be harvested about 105 days, yielding an average of $722 \mathrm{~kg} /$ rai. The trunk has a height of about $95-116 \mathrm{~cm}$. and the clump is set and the stems are very hard with leaf sheaths and green leaves providing good physical seed quality, long slender seed shape, straw paddy seed, white brown rice, good color quality that can be colored as 100 percent rice. It will get the quality of soft cooked rice (Rice Department, 2018).

\section{Concepts and theories of costs of production}

Office of Agricultural Economics (2014) has given the definition of production cost as the cost or value of the use of production factors for both variable types and constant factors used for the production to proceed until the end of the process in a given period.

Both variables and fixed factors will create a total cost which is the sum of all costs in cash and non-cash. Additionally, Krootboonyong Ch., (2012) gives the definition of the cost, which means the expenses paid to produce the product consisting of fixed cost and variable cost that can be classified by type of cost as follows: (Thongdeerawisuraket P., 2016)

1. Fixed Cost means the cost of production for each period which has a constant condition and not changing in the size of production. This type of production factor still occurs, no matter how much production produce little or no production such as land use, depreciation, etc.

2. Variable cost means the cost of production that can change in the size of usage which the yield will be depending on the size of the factor. If there is a change in the use of factors, the result in the size of the product also changed, including raw materials, labor costs and production costs. 


\section{Theory of return and analysis of return on investment}

Return on investment refers to the amount investors expect from investment in the business (Khumsub P., 2011) or what is obtained from the use of resources that are used to invest in production and can get it back in the form of money or other non-monetary factors (Chanchoungchote W., 2014).

Analysis of return on investment is a purpose to analyze the projects that are worth with the investment which can be divided into 2 types: analysis methods with discounted methods and analytical methods without discounting. (Undiscounted Approach) (Techaseub P., 2014). This research will study only the method of analysis without discounting (Undiscounted approach) consisting of break-event point analysis, net profit margin to cost ratio, net profit to sales ratio and return on investment.

\section{Research Methodology}

This research is a qualitative research that the data were collected by in-depth interview from the interview question form as a tool to collect data, consisting of raw material costs, labor costs, production costs, production and average income per rai. The population used in the research is the farmers who are members of Sam Chuk Agricultural Cooperative, who planted RD 41 rice and have cultivated areas ranging from 10 - 50 rai by using a random sampling technique of 10 cases and quantitative data analysis such as cost, revenue, net profit, break-even point, Net profit to cost ratio, Net profit to sales ratio and return on investment (ROI).

\section{Findings}

The researcher collected data of 10 farmers who are members of Sam Chuk Agricultural Cooperative District, who planted RD 41 rice and have cultivated areas from 10 to 50 rai. The number of analysis can be shown as follows:

Table 2: Average cost of rice production per rai (282 Rai data collection area).

\begin{tabular}{llr}
\hline & Transaction & Amount (Baht per rai) \\
\hline Raw material cost & Rice seed & 553.69 \\
Labor cost & Sowing wages & 553.69 \\
& Wage for fertilizing & $1,632.77$ \\
& Wage for spraying & 50 \\
& Wage for seizure & 180 \\
& Self-labor cost & 150 \\
Production cost & & 40 \\
& Plowing wages & $1,212.77$ \\
& Fertilizer & $2,401.80$ \\
& Herbicides & 280 \\
& Pesticides & 855.60 \\
& Hormone maintenance rice & 88 \\
& Fuel cost & 56 \\
& Harvester wages & 28 \\
& Depreciation & 200 \\
& \multicolumn{1}{c}{ Total cost } & 500 \\
& & 394.20 \\
\hline
\end{tabular}


From Table 2, the analysis of data and cost structure of rice cultivars, RD 41, found that the total cost of the average was $4,588.26$ baht per rai, the average raw material cost of 553.69 baht per rai or 12.06 percent, the average labor cost was $1,632.77$ baht per rai or 35.59 percent, and the average production cost of 2,401.80 baht per rai or 52.35 percent.

Table 3: Profit (Loss) from rice cultivation, RD 41, average per rai.

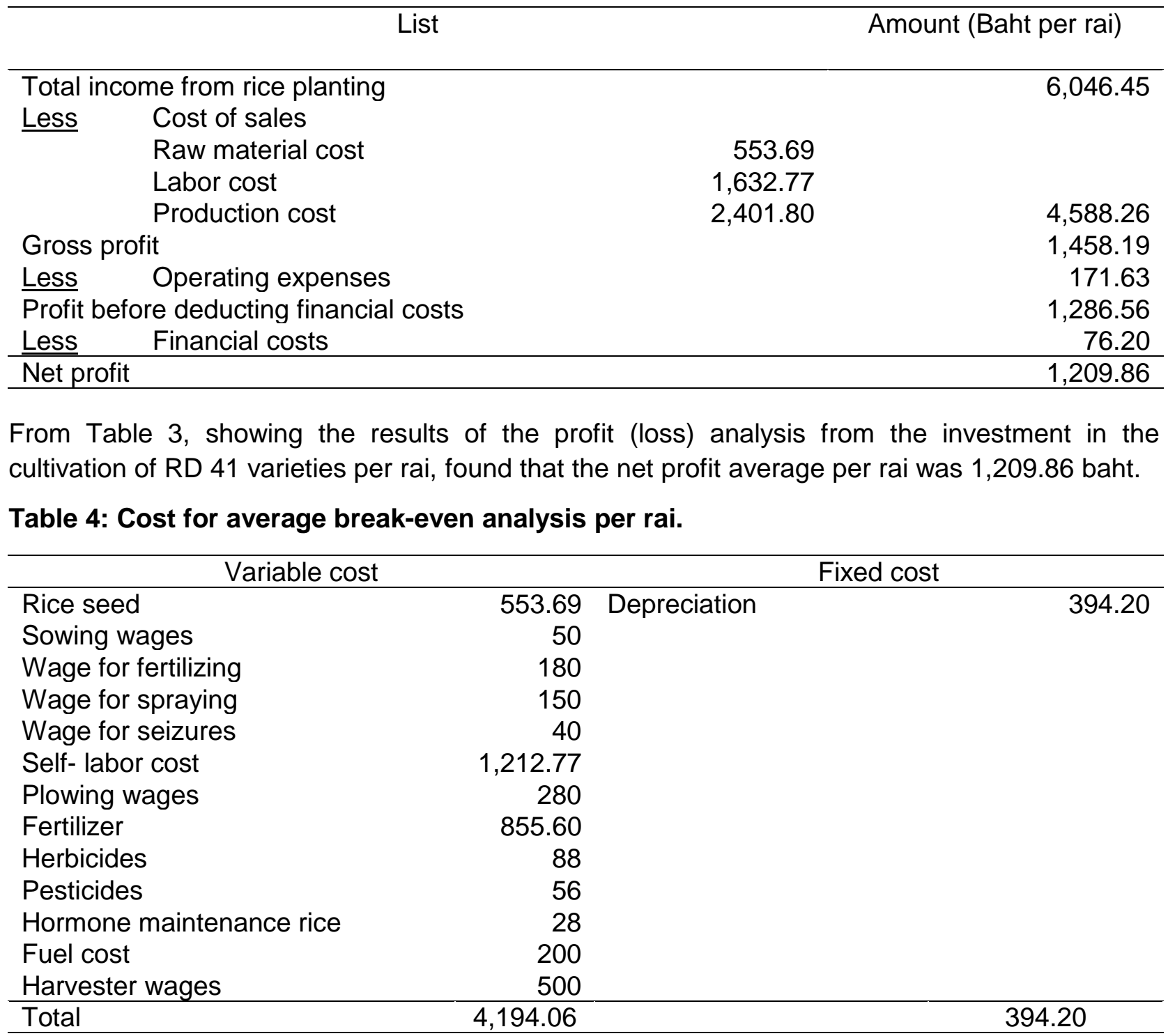

From Table 4, showing the type of cost for average break-even analysis per rai which found that the average variable cost per rai was 4,194.06 baht, he average fixed cost per rai was 394.20 baht and the break-even point could be calculated from the following formula:

Break-even point $=$ fixed cost / (selling price per unit - variable cost per unit)

Breakeven point $=394.20 /(6,046.45-4,194.06)=0.21$ tons 
From the calculation of the break-even point, it was found that the farmer had to plant the RD 41 rice to yield 0.21 tons per rai. Therefore, it would be worthwhile and the study of the return on investment of RD 41 rice varieties can be focused the profit margin per cost, profit margin per sales and return on investment as shown in Table 5.

Table 5: Calculation of return on investment of RD 41 rice varieties per rai.

\begin{tabular}{lccc}
\hline \multicolumn{1}{c}{ Ratio } & Formula (per rai) & Calculation & Result \\
\hline Net profit to cost ratio & $\frac{\text { Net Profit }}{\text { Cost }}$ & $\frac{1,209.86}{4,588.26}$ & 26.37 \\
\hline Net profit to sales ratio & $\frac{\text { Net Profit }}{\text { Sale }}$ & $\frac{1,209.86}{6,046.45}$ & 20.01 \\
\hline Return on investment & $\frac{\text { Net Profit }}{\text { Investment }}$ & $\frac{1,209.86}{5,367.80}$ & 22.54 \\
\hline
\end{tabular}

From Table 5, the calculation of the return on investment of RD 41 rice yield per rai found that a margin per cost of 26.37 percent, profit per sales ratio of 20.01 percent and a return on investment of 22.54 percent

\section{Conclusion}

Growing rice varieties RD 41 of the members of Sam Chuk District Agricultural Cooperative with a cultivation area of 10 - 50 rai had an average cost of $4,588.26$ baht per rai, an average raw material cost of 553.69 baht per rai or 12.06 percent, an average labor cost of 1,632.77 baht per rai or 35.59 percent and an average production cost of 2,401.80 baht per rai or 52.35 percent, average net profit per rai of $1,209.86$ baht, break-even point is 0.21 tons per rai, Net profit to cost ratio of 26.37 percent, Net profit to sales ratio of 20.01 percent and return on investment of 22.54 percent.

\section{Interpretation of the results}

The cost of rice cultivation, RD 41, consists of 3 important parts: raw material, $12.06 \%$, labor cost, $35.59 \%$ and production cost, $52.35 \%$, which can be seen that the proportion of production costs is the highest. This is consistent with the study of Pajai T. et al., (2016) and Yawijai P. et al., (2018)., which caused farmers to hire a tractor and combine harvesters. Additionally, the use of chemical fertilizers or chemicals in the production process can increase the amount of production including water, fuel and higher prices resulting in higher production costs.

Return on investment in rice cultivation, RD 41, with an average net profit of 1,209.86 baht per rai, Net profit to cost ratio of 26.37 percent, Net profit to sales of 20.01 percent, and return on investment of 22.54 percent is a low return rate. This is consistent with the study of Tornpanya S. (2011) with a proportion of returns in the investment of rice farmers, Moo 5, Hua Dong Subdistrict, Mueang District, Phichit Province that is relatively low due to the high rice production costs of farmers compared to the income after deducting costs and expenses. 


\section{Suggestions}

From the research, it was found that the cost of investing in the cultivation of RD 41 rice is quite high when considering production costs and most of them were fertilizer cost, wages, plowing, wages, combine harvesters which farmers may consider reducing fertilizer costs by using organic fertilizers instead of chemical fertilizers and farmers should have selected seeds to grow themselves in the growing season to reduce the cost of buying seeds from external sources.

\section{Suggestions for future research}

The researchers should study the costs and returns of other varieties of rice that are popular for selected in the same area which can be compared for the decision of rice varieties to invest in the next season.

\section{References}

Chanchoungchote, W. (2014). Comparison of cost and return on hom mali 105 rice cultivation between scattering and scattering with transplanting methods of farmers in samrongtarb district, Surin province. Independent Study. Master degree, Rajamangala University of Technology Thanyaburi, Pathumtani.

Krootboonyong, C. (2012). Business Finance. Bangkok: Se-Education Public Company Limited.

Office of Agricultural Economics. (2014). "Definition of production cost of agricultural products".[OnlineAvailable]:http://www.oae.go.th/assets/portals/1/files/ebook/definition(1).pdf. (Accessed September 2018).

Policy and Planning Bureau. (2018). "Production and marketing information of 6 major agricultural products, 2018/2019". [On-line Available]: go.th/ midev10/upload/2161.pdf. (Accessed September 2018).

Rice Department. (2018). "Knowledge of rice". [On-line Available]: http://www.rice thailand.go.th/Rkb/varieties/index.phpfile=content.php\&id=121.htm. (Accessed September 2018).

Social Economic Information Suphanburi Province. (2018) "Important economic crops of Suphanburi Province" [On-line Available]: http://www.spvc.ac.th/datacenter/

data_suphanburi.pdf. (Accessed September 2018).

Suphanburi provincial agricultural extension office. (2018). "Agricultural area in Suphanburi province".[On-lineAvailable]:http://www.suphanburi.doae.go .th/. (Accessed September 2018).

Thailand Trading Report. (2018). "Exporting Thai important products". [On-line Available]: http://www.ops.moc.go.th/export/recode_export_rank/report.asp.(Accessed September 2018).

Thongdeerawisuraket, P. (2016). Comparative analysis between the production cost and return on rice production of farmer group in Kanchanaburi province. Research report of Rajamangala University of Technology Rattanakosin, Nakhonpathom. 